\title{
Vimentin and cytokeratin expression in nodular hyperplasia and carcinoma of the prostate
}

\author{
M Heatley, P Maxwell, C Whiteside, P Toner
}

\begin{abstract}
Aim-To assess the value of vimentin and cytokeratin (CK) intermediate filament proteins (IFPs) in distinguishing between nodular hyperplasia and carcinoma of the prostate and in predicting prognosis in prostatic cancer.

Methods-Fifteen carcinomas and 49 cases of nodular hyperplasia were studied using frozen sections and monoclonal antibodies to $C K$ and vimentin IFPs.

Results-There was no statistically significant difference in vimentin expression between nodular hyperplasia and carcinoma. The luminal epithelium in both also reacted with antibodies which detect CK8, 18 and 19. CK 7 expression was found in $57 \%$ of cases of nodular hyperplasia and was not identified in any carcinoma. There was a reaction with antibodies to $\mathrm{CK} 1,2$, $3,4,10,11$, and 13 in only a minority of cases. There was no statistically significant difference in vimentin and $C K$ reactivity in high and low grade carcinomas.

Conclusion-Neither vimentin nor CK expression assists in establishing whether a prostatic lesion is benign or malignant or in predicting the biological behaviour of a prostatic carcinoma.

(f Clin Pathol 1995;48:1031-1034)
\end{abstract}

Keywords: Intermediate filament proteins, prostate, hyperplasia, neoplasia.

Pathology,

The Royal Victoria

Hospital,

Grosvenor Road,

Belfast BT12 6BA

$M$ Heatley

P Maxwell

C Whiteside

$\mathrm{P}$ Toner

Correspondence to:

Mr P Maxwell.

Accepted for publication 1 June 1995

Table 1 The specificities of the antibodies used in this study

\begin{tabular}{llll}
\hline Antibody clone no. & Specificity & Supplier & $\begin{array}{l}\text { Dilution on } \\
\text { cryostat sections }\end{array}$ \\
\hline V9 & Vimentin & Dako & 1 in 5 \\
Cam 5.2 & CK8,18,19 & Becton Dickinson & 1 in 10 \\
LP34 & CK6,18 & Dako & 1 in 10 \\
AE1 & CK10,14,15,16,19 & ICN & 1 in 50 \\
AE3 & CK1-8 & ICN & 1 in 50 \\
AE2 & CK1,2,10,11 & ICN & 1 in 50 \\
AE5 & CK3 & ICN & 1 in 50 \\
AE8 & CK13 & ICN & 1 in 50 \\
RCK105 & CK7 & Europath & 1 in 20 \\
M20 & CK8 & ICN & 1 in 20 \\
RGE53 & CK18 & ICN & 1 in 20 \\
BA17 & CK19 & Dako & 1 in 10 \\
RCK102 & CK5 and 8 & Europath & 1 in 20 \\
6B10 & CK4 & Europath & 1 in 20 \\
RSKE60 & CK10 & Europath & 1 in 20 \\
\hline
\end{tabular}

Source: Dako, High Wycombe, UK; ICN, Thame, UK; Europath, Bude, UK; Becton Dickinson, Gosport, UK. Of the five distinct classes of cytoplasmic inare normally expressed in epithelial cells and vimentin in mesenchymal cells. ${ }^{12}$ Tumours usually express the intermediate filament proteins characteristic of their tissue of origin..$^{3-5}$

Expression of cytokeratin in prostatic epithelium is well recognised. ${ }^{6-14}$ The additional expression of vimentin ${ }^{9}$ in hyperplastic and neoplastic prostatic epithelium has also been described. It has been suggested that in tumours, vimentin expression correlates with histological grade. ${ }^{9}$

This paper evaluates the use of antibodies to vimentin and cytokeratin intermediate filament proteins in differentiating between benign and malignant prostatic disease and in predicting prognosis in prostatic carcinoma.

\section{Methods}

Fresh transurethral resection specimens from 64 patients undergoing prostatectomy for malignant (15 cases) and benign (49 cases) disease were studied. As the immunoreactivity of intermediate filament proteins is best preserved on frozen sections, ${ }^{215} 5 \mu \mathrm{m}$ serial frozen sections were stained using antibodies to vimentin and cytokeratins, using the indirect immunoperoxidase method (table 1). Brown granular cytoplasmic staining was taken to denote a positive reaction. Cases were graded between 1 and 5 depending on whether under $25 \%, 26-50 \%, 51-75 \%, 76-99 \%$, or $100 \%$ of the cells reacted with the antibody under study.

The proportions of immunoreactive luminal epithelial cells in cases of nodular hyperplasia, and of malignant tumour cells in prostatic carcinomas, were compared using the Mann-Whitney $U$ test. The reaction of the basal epithelial cells to each antibody was also noted. Differences in expression were considered significant if the $p$ value was $0.05(5 \%)$ or less.

Using the method of Gleason et al, ${ }^{16}$ malig-

nant tumours were grouped into low (Gleason score 2-4), intermediate (Gleason score 5-7) and high grade (Gleason score 8-10) lesions. To assess these intermediate filament antibodies as indicators of prognosis, the proportions of immunoreactive cells in the low and high grade tumours were compared using the Mann-Whitney $U$ test. The single intermediate grade tumour was not included in this analysis.

\section{Results}

Vimentin was expressed more frequently in nodular hyperplasia $(73 \%)$ than in carcinoma $(60 \%)$ of the prostate. The proportions of cells reacting with the antibody to vimentin in the two groups were not significantly different $(\mathrm{p}=$ 0.0512 ) (table 2).

A positive reaction with Cam 5.2, LP34, AE1, AE3, RCK102, and with the specific antibodies directed against CK8, 18 and 19 was seen in the luminal epithelium in most 


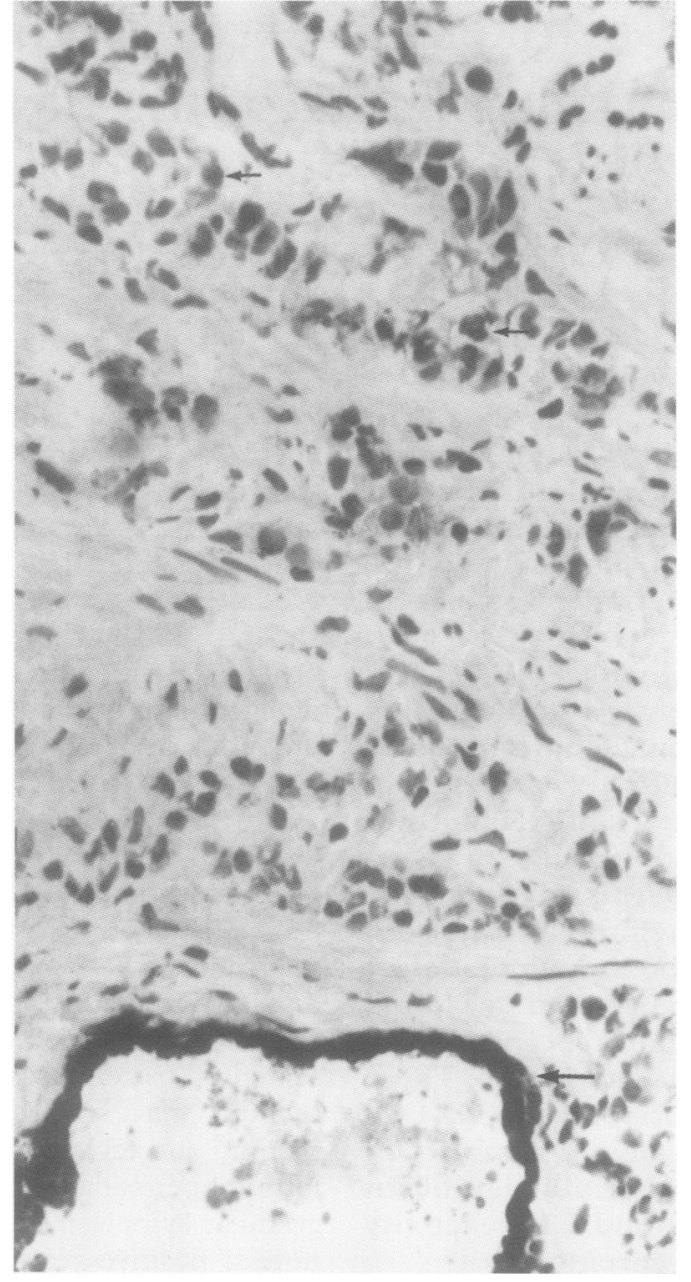

Figure 1 Tumour cells in this case of adenocarcinoma of the prostate fail to react with the specific antibody to $C K 7$ (small arrows). The luminal epithelium in an adjacent benign duct reacts with the antibody (large arrows). (Frozen section; original magnification $\times 320$.)

cases of nodular hyperplasia and in tumour cells in most cases of prostatic adenocarcinoma. Although CK7 (RCK105) was expressed by luminal epithelium in $57 \%$ of cases of nodular hyperplasia, it was not detected in any case of prostatic adenocarcinoma (figs 1 and 2). This difference remained statistically significant at the $5 \%$ level even after taking account of the large number of antibodies tested, by applying

Table 2 The number of cases of adenocarcinoma and nodular hyperplasia of the prostate which reacted with antibodies to intermediate filament proteins. The percentage of cases is shown in brackets

\begin{tabular}{|c|c|c|c|c|}
\hline \multirow[b]{2}{*}{ Antibody } & \multirow{2}{*}{$\frac{\text { Adenocarcinoma of prostate }}{\text { Positive }}$} & \multirow{2}{*}{$\frac{\text { Nodular hyperplasia }}{\text { Positive }}$} & \multicolumn{2}{|c|}{ Mann-Whitney U test } \\
\hline & & & p value & \\
\hline Vimentin & $9(60 \%)$ & $36(73 \%)$ & 0.0512 & NS \\
\hline Cam $5 \cdot 2$ & $15(100 \%)$ & $49(98 \%)$ & $0 \cdot 13$ & NS \\
\hline LP 34 & $14(95 \%)$ & $48(96 \%)$ & 0.65 & NS \\
\hline $\mathrm{AE} 1$ & $11(79 \%)$ & $44(88 \%)$ & 0.58 & NS \\
\hline AE3 & $14(100 \%)$ & $47(96 \%)$ & $0 \cdot 48$ & NS \\
\hline AE2 & $1(8 \%)$ & $1(3 \%)$ & 0.40 & NS \\
\hline AE5 & $4(31 \%)$ & $16(43 \%)$ & 0.62 & NS \\
\hline AE 8 & $1(8 \%)$ & $1(3 \%)$ & $0 \cdot 40$ & NS \\
\hline RCK105 & $0(0 \%)$ & $21(57 \%)$ & 0.0004 & Significant \\
\hline BA17 & $10(66 \%)$ & $39(87 \%)$ & 0.45 & NS \\
\hline M20 & $8(100 \%)$ & $17(94 \%)$ & 0.52 & \\
\hline RGE53 & $7(100 \%)$ & $16(100 \%)$ & $0 \cdot 15$ & NS \\
\hline RCK102 & $13(100 \%)$ & $35(95 \%)$ & 0.32 & \\
\hline $6 \mathrm{~B} 10$ & $2(15 \%)$ & $15(41 \%)$ & 0.09 & $\mathbf{N}$ \\
\hline RSKE60 & $0(0 \%)$ & $1(3 \%)$ & 0.55 & $\mathrm{~N}$ \\
\hline
\end{tabular}

The proportions of tumour cells in cases of adenocarcinoma, and luminal epithelial cells in cases of nodular hyperplasia were compared using the Mann-Whitney U test. NS = not significant. the Bonferroni correction. A positive reaction with the other antibodies occurred in only a minority of cases of nodular hyperplasia and adenocarcinoma.

A summary of the number of cases of prostatic carcinoma which reacted to each antibody is presented, by tumour grade, in table 3. There were no significant differences in the proportions of tumour cells reacting with the various antibodies to vimentin and cytokeratins in high and low grade carcinomas.

Basal epithelial cells were identified only in cases of nodular hyperplasia and in the benign glands adjacent to areas of adenocarcinoma (table 4). Most cases were positive for vimentin, Cam 5·2, LP34, AE1, AE3, and RCK102.

\section{Discussion}

This study was carried out to assess whether intermediate filament expression differed between benign and malignant prostatic disease and whether immunostaining in prostatic carcinoma could be correlated with tumour grade and thus indirectly with prognosis. The rationale is provided by cell culture experiments, where the transformation of cells to a malignant phenotype may be associated with vimentin expression. ${ }^{1718}$ Changes in cytokeratin ex-

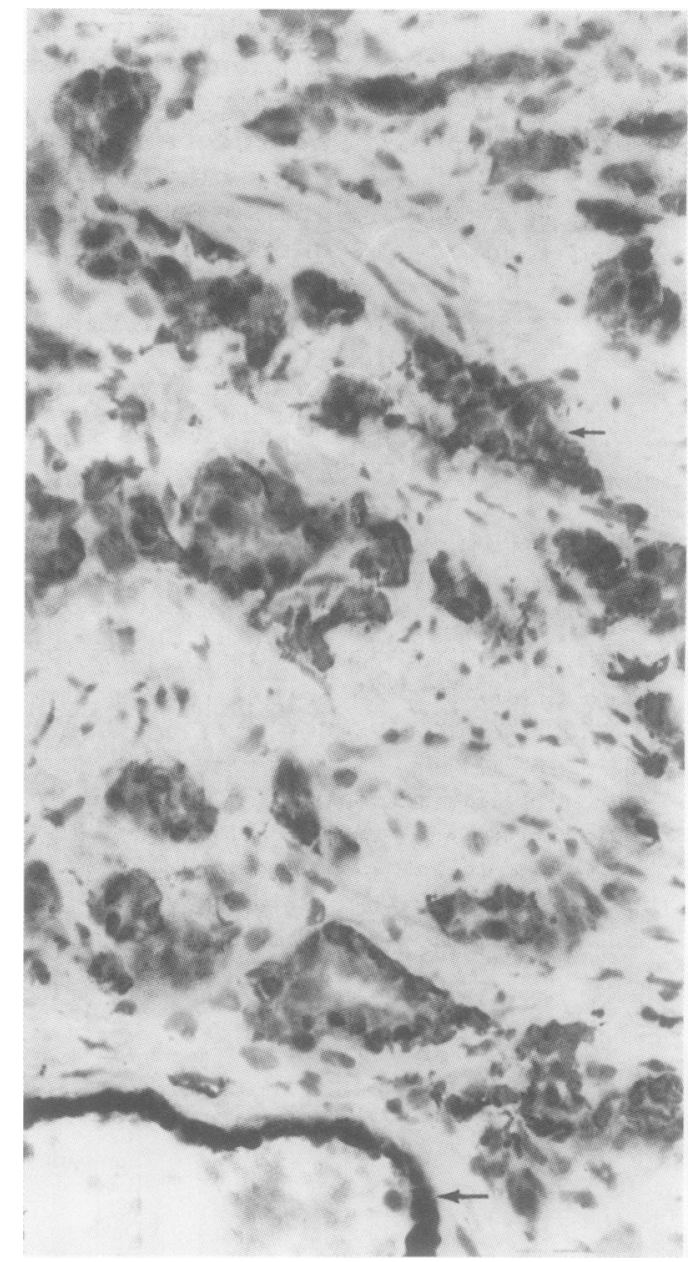

Figure 2 In an adjacent section to that shown in fig 1, expression of CK8 was detected in both the malignant (small arrows) and benign (large arrows) epithelial cells. (Frozen section; original magnification $\times 320$.) 
Table 3 Numbers of prostatic carcinomas reacting to each antibody presented by tumour grade

\begin{tabular}{|c|c|c|c|c|c|}
\hline \multirow[b]{3}{*}{ Antibody } & \multirow[b]{3}{*}{$\begin{array}{l}\text { Not reacting } \\
\text { to antibody }\end{array}$} & \multicolumn{4}{|c|}{ Reacting with antibody } \\
\hline & & \multicolumn{3}{|l|}{ Gleason group } & \multirow[b]{2}{*}{$\begin{array}{l}\text { Mann-Whitney } U \\
\text { test }(p-\text {-value })\end{array}$} \\
\hline & & $\begin{array}{l}\text { Low (Gleason } \\
\text { score } 2-4)(n=6)\end{array}$ & $\begin{array}{l}\text { Intermediate (Gleason } \\
\text { score 5-7) }(n=1)\end{array}$ & $\begin{array}{l}\text { High (Gleason score } \\
8-10)(n=8)\end{array}$ & \\
\hline Vimentin & 6 & 4 & 1 & 1 & $0.38 \mathrm{NS}$ \\
\hline Cam $5 \cdot 2$ & 0 & 6 & 1 & 8 & $0.81 \mathrm{NS}$ \\
\hline LP34 & 1 & 6 & 1 & 7 & $1 \cdot 00 \mathrm{NS}$ \\
\hline $\mathrm{AE} 1$ & 3 & 5 & 0 & 6 & $0 \cdot 15$ NS \\
\hline $\mathrm{AE} 3$ & 0 & 5 & 1 & 8 & 0.07 NS \\
\hline $\mathrm{AE} 2$ & 12 & 1 & 0 & 0 & 0.24 NS \\
\hline $\mathrm{AE} 5$ & 9 & 3 & 0 & 1 & $0 \cdot 14$ NS \\
\hline AE8 & 12 & 0 & 0 & 1 & $0.40 \mathrm{NS}$ \\
\hline RCK105 & 14 & 0 & 0 & 0 & 1.00 NS \\
\hline BA17 & 5 & \multirow{2}{*}{\multicolumn{4}{|c|}{ All tumour cells reacted with this antibody }} \\
\hline M20 & 0 & & & & \\
\hline RGE53 & 0 & 3 & 1 & 1 & $0 \cdot 24 \mathrm{NS}$ \\
\hline RCK102 & 0 & 5 & 1 & 7 & 0.63 NS \\
\hline $6 \mathrm{~B} 10$ & 11 & 1 & 0 & 1 & $0.80 \mathrm{NS}$ \\
\hline RSKE60 & 13 & 0 & 0 & 0 & $1.00 \mathrm{NS}$ \\
\hline
\end{tabular}

The proportion of cells in the high and low grade carcinomas were compared using the Mann-Whitney U Test. Note: The single case falling into the intermediate group was excluded from this analysis. NS $=$ not significant.

pression $^{18}$ following neoplastic transformation have also been described in cell culture experiments and in human tissues. ${ }^{611}$

Vimentin expression was more commonly detected in benign than malignant disease on frozen sections, confirming the observations of Leong et al. ${ }^{9}$ The identification of this protein in an individual case is, therefore, not indicative of malignant disease of the prostate.

Sherwood et $a l^{19}$ identified expression of CK5 $, 7,8,15,18,19$, and trace amounts of CK13 on immunoblot analysis of the luminal epithelium of normal prostates and cases of nodular hyperplasia. Predictably, therefore, in the present study, the antibodies which reacted most frequently in cases of nodular hyperplasia were those directed against one or more of these cytokeratins.

Chou $e t a l^{6}$ have reported a difference in the percentage of cells reacting with anti-cytokeratin antibodies in adenocarcinoma and nodular hyperplasia. In the present study, however, most of the antibodies which reacted with the luminal epithelium in nodular hyperplasia and with tumour cells in cases of carcinoma did so in approximately equal proportions of cases (table 2).

CK7 was not identified in any case of prostatic carcinoma, but was usually detected in

Table 4 The reaction of basal epithelial cells (on frozen sections), in cases of nodular hyperplasia, with antibodies to intermediate filament proteins

\begin{tabular}{|c|c|c|c|c|c|c|c|c|}
\hline \multirow[b]{2}{*}{ Antibody } & \multicolumn{7}{|c|}{ Grade } & \multirow{2}{*}{$\begin{array}{l}\text { Total no. of } \\
\text { cases examined }\end{array}$} \\
\hline & 0 & & 1 & 2 & 3 & 4 & 5 & \\
\hline Vimentin & 0 & $(0 \%)$ & 3 & 5 & 7 & 6 & 27 & 48 \\
\hline Cam $5 \cdot 2$ & 10 & $(21 \%)$ & 3 & 2 & 2 & 4 & 27 & 48 \\
\hline LP34 & 1 & $(2 \%)$ & 1 & 3 & 1 & 6 & 27 & 39 \\
\hline AE1 & 1 & $(2 \%)$ & 2 & 1 & 4 & 17 & 23 & 48 \\
\hline AE3 & 2 & $(4 \%)$ & 3 & 6 & 2 & 12 & 23 & 48 \\
\hline AE2 & 31 & $(86 \%)$ & 3 & 1 & 1 & 0 & 0 & 36 \\
\hline AE5 & 14 & $(41 \%)$ & 5 & 0 & 3 & 2 & 10 & 34 \\
\hline AE8 & 33 & $(97 \%)$ & 0 & 1 & 0 & 0 & 0 & 34 \\
\hline RCK105 & 19 & $(56 \%)$ & 10 & 4 & 0 & 1 & 0 & 34 \\
\hline BA17 & 10 & $(24 \%)$ & 7 & 5 & 4 & 6 & 10 & 42 \\
\hline M20 & 4 & $(27 \%)$ & 0 & 0 & 1 & 0 & 10 & 15 \\
\hline RGE53 & 9 & $(69 \%)$ & 1 & 0 & 0 & 2 & 1 & 13 \\
\hline RCK 102 & 4 & $(11 \%)$ & 1 & 4 & 5 & 2 & 20 & 36 \\
\hline $6 \mathrm{~B} 10$ & 30 & $(83 \%)$ & 3 & 3 & 0 & 0 & 0 & 36 \\
\hline RSKE60 & 32 & (97\%) & 0 & 0 & 0 & 1 & 0 & 33 \\
\hline
\end{tabular}

Grade: $0=$ no reactive cells; $1=<25 \%$ reactive cells; $2=26-50 \%$ reactive cells; $3=51-75 \%$ reactive cells; $4=76-99 \%$ reactive cells; $5=100 \%$ reactive cells. nodular hyperplasia. Although these findings are in agreement with those of Raemakers $e t$ $a l,{ }^{11} \mathrm{CK} 7$ expression was recently described in a single prostatic carcinoma. ${ }^{20}$

Although of little help in distinguishing benign epithelium from malignant epithelium, some of these monoclonal antibodies could be potentially useful in identifying invasive tumours, as they react with the basal cells which surround foci of in situ carcinoma and which are present in prostatic acini in benign conditions. Srigley et $a l^{12}$ described CK14 expression in the basal epithelium of nine cases of nodular hyperplasia. CK14 is usually expressed in association with CK5. Although antibodies specific to these cytokeratins were not included in the present series, AE1, which includes CK14 in its spectrum, detected basal cells in $98 \%$ of cases and RCK102 and AE3, which detect CK5, stained basal cells in $96 \%$ and $89 \%$ of cases, respectively. All three antibodies have been reported as suitable for use on formalin fixed material ${ }^{13}$ and may have a role in distinguishing basal epithelial cells from stromal cells. We also found that antibodies to CK7, 18 and 19 reacted with the basal epithelium, as described elsewhere. ${ }^{8101213}$

Although cell culture experiments indicate that vimentin expression occurs in tumour cells in association with the more malignant phenotype ${ }^{18}$ in contrast to the findings of previous studies $^{12}$ it was not possible to demonstrate a statistically significant association between vimentin expression and increasing tumour grade.

Reduced cytokeratin expression has been described in vitro with increasing histological grade of transitional cell carcinoma ${ }^{21}$ and in more tumorigenic cell lines. ${ }^{18}$ In the present study differences in the proportions of cases of prostatic tumours of different histological grade which reacted with particular antibodies, were not statistically significant. Thus neither vimentin nor cytokeratin expression showed a significant association with this known prognostic indicator.

In conclusion, vimentin expression does not distinguish between nodular hyperplasia and carcinoma of the prostate, as it occurs in both. 
Although CK7 and 13 were not expressed in any case of carcinoma of the prostate, they were also absent in some cases of nodular hyperplasia and did not assist in differentiating between the two lesions. High and low grade carcinomas of the prostate cannot be distinguished by their expression either of vimentin or of individual cytokeratins.

We acknowledge the financial assistance provided by The Ulster Cancer Foundation and The Royal Hospitals Trust. We are grateful to Mrs E McNamee for typing the manuscript and $\mathrm{Mr}$ grateful to Mrs E McNamee for typing the manuscript and $\mathrm{Mr}$ $\mathrm{R}$ Creighton for photographic assistance. We are grateful to
Messrs S R Johnstone and J Kennedy for permission to study Messrs S R Johnstone and J
the patients under their care.

1 Fuchs E. Keratins as biochemical markers of epithelia differentiation. Trends Genet 1988;4:227-81.

2 Nagle RB. Intermediate filaments: A review of the basic biology. Am f Surg Pathol 1988;12(Suppl 1):4-16.

3 Domagala W, Lubinski J, Weber K, Osborn M. Intermediate filament typing of tumor cells in fine needle aspirates by means of monoclonal antibodies. Acta Cytol 1986;30: 214-24.

4 Lehto VP, Miettinen M, Virtanen I. Antibodies to intermediate filaments in surgical pathology. Arch Geschwulst Forsch 1986;56:283-98.

5 Osborn M, Weber K. Biology of disease. Tumor diagnosis by intermediate filament typing: a novel tool for surgical pathology. Lab Invest 1983;48:372-93.

6 Chou P, Ray V, Shaw M, Rubenstein M, Guinan P. An immunohistologic characterization of human prostatic immunohistologic characterization of huma

7 Daher N, Bove N, Bara J, Abourachid H. Value of different markers in prostatic carcinomas. An immunohistological study. Prog Clin Biol Res 1987;243:507-10.

8 Feitz WFJ, Debruyne FMJ, Vooijs GP, Herman CJ, Ramaekers FCS. Intermediate filament proteins as tissue specific markers in normal and malignant urological tissues. F Urol 1986;136:922-31.

9 Leong AS-Y, Gilham P, Milios J. Cytokeratin and vimentin intermediate filament proteins in benign and neoplastic prostatic epithelium. Histopathology 1988;13:435-42.

10 Purnell DM, Heatfield BM, Anthony RL, Trump BF. Im- munohistochemistry of the cytoskeleton of human prostatic epithelium. Evidence for disturbed organization in neoplasia. Am f Pathol 1987;126:384-95.

11 Ramaekers F, van Niekerk C, Poels L, Schaafsma E, Huijsmans A, Robben $\mathrm{H}$, et al. Use of monoclonal antibodies to keratin 7 in the differential diagnosis of adenocarcinomas. Am f Pathol 1990;136:641-55.

12 Srigley JR, Dardick I, Warren R, Hartwick I, Klotz L. Basal epithelial cells of human prostate gland are not myoepithelial cells. A comparative immunohistochemical myoepithelial cells. A comparative immunohistochemical and ultrastructural study with

13 Svanholm H, Nielsen B, Starklint H. Keratin patterns in prostatic hyperplasia and adenocarcinoma. APMIS 1988 (Suppl 4):100-8.

14 Van Niekerk CC, Jap PHK, Ramaekers FCS, Van De Molengraft F, Poels LG. Immunohistochemical demonstration of keratin 7 in routinely fixed paraffin-embedded human tissues. $\mathcal{F}$ Pathol 1991;165:145-52.

15 Azumi N, Battifora $H$. The distribution of vimentin and keratin in epithelial and nonepithelial neoplasms. A comprehensive immunohistochemical study on formalin - and prehensive immunohistochemical study on formalin - and

16 Gleason DF, Mellinger GT and the Veterans Administration Cooperative Urological Research Group. Prediction of prognosis for prostatic adenocarcinoma by combined histological grading and clinical staging. $\mathcal{F}$ Urol 1974;111: 58-64.

17 Mork C, van Deurs B, Petersen OW. Regulation of vimentin expression in cultured human mammary epithelial cells. Differentiation 1990;43:146-56.

18 Sommers CL, Walker-Jones D, Heckford SE, Worland P, Valverius E, Clark R, et al. Vimentin rather than keratin expression in some hormone-independent breast cancer cell lines and in oncogene-transformed mammary epithelial cells. Cancer Res 1989;49:4258-63.

19 Sherwood ER, Berg I A Mitchell NJ, McNeal JE, Kozlowski

JM, Lee C. Differential cytokeratin expression in normal JM, Lee C. Differential cytokeratin expression in normal,
hyperplastic and malignant epithelial cells from human hyperplastic and malignant epithel

prostate. F Urol 1990;143:167-71.
20 Okada H, Tsubura A, Okamura A, Senzaki H, Naka Y, Komatz $\mathrm{Y}$, et al. Keratin profiles in normal hyperplastic prostates and prostatic carcinoma. Virchow Arch A Pathol Anat Histopathol 1992;421:157-61.

21 Schaafsma HE, Ramaekers FCS, van Muijen GNP, Lane EB, Leigh IM, Robben $\mathrm{H}$, et al. Distribution of cytokeratin polypeptides in human transitional cell carcinomas, with special emphasis on ch tumor progression. Am 7 Pathol 1990;136:329-43. 